JOSEPH G. KICKASOLA

Baylor University

New York
Images

vol. XXIV/no. 33

Poznań 2018

ISSN 1731-450X

\title{
Inflancka Travelogue: 10 Short Essays on "Decalogue"
}

\begin{abstract}
Aвstract. Joseph G. Kickasola, Inflancka Travelogue: 10 Short Essays on "Decalogue”. "Images" vol. XXIV, no. 33, Poznań 2018. Adam Mickiewicz University Press. Pp. 19-38. ISSN 1731-450X. DOI 10.14746/i.2018.33.03.

Kieślowski scholar Joseph G. Kickasola documents his efforts to find and explore the Warsaw apartment complex where Krzysztof Kieślowski filmed his Decalogue series. His startling, unexpectedly emotional experience at such an ordinary place becomes an opportunity to reflect on the films, theorize on the function of place in them, and consider the way that human life and cinema feed into each other. Fictional stories and their cinematic constructions can deepen our experience, and make the world feel more lived in, more true. Nothing magical happened, but everything ordinary happened in all its fullness, like a kind of prophecy, fulfilled.
\end{abstract}

KeYwORDs: Krzysztof Kieślowski, Decalogue, motor intentionality, spatial dynamics, phenomenology, embodiment

Locked within a Lacanian gaze, whose spatial impact remained unexplored, the film spectator was turned into a voyeur.

By contrast [...] because of film's spatio-corporeal mobilization, the spectator is rather a voyageur, a passenger who traverses a haptic, emotive terrain.

- Giuliana Bruno[1]

Maurice Merleau-Ponty called it "motor intentionality".[2] That is, we all have foundational, skillful, unreflective epistemological processes that are forms of knowledge in themselves. These bodily and cognitive "sets" of corporeal knowledge are born of experience, always, already, engaging with the world, and ever evolving. As he teases out this idea, Merleau-Ponty argues this is all the body's expression of "spatiality", not as "position", but "situation".[3] Concepts are secondary:

Sight and movement are specific ways of entering into relationship with objects and if, through all these experiences, some unique function finds its expression, it is the momentum of existence, which does not cancel out the radical diversity of contents, because it links them to each other, not

\section{Wandering, but Not Lost}

[2] M. Merleau-Ponty, Phenomenology of Perception, tran. C. Smith, London 2002, pp. 158-159.

[3] Ibidem., pp. 114-115.
[1] G. Bruno, Atlas of Emotion: Journeys in Art, Architecture, and Film, New York 2002, pp. 15-16. 
by placing them all under the control of an "I think", but by guiding them towards the intersensory unity of a "world".[4]

This means for him that the essence of human consciousness is not "I think" but "I can",[5] and the goal of consciousness is a coherent, unified, fully realized world.

Our bodies constantly grasp for meaning. When we stumble on something that offers a rich source of interaction, particularly if it rings familiar on some level, we strain to meet it with all the experiential knowledge we have. In the best pairings, our whole bodies and the world dance together.

As I moved through Warsaw, near Inflancka Street, that sense of reach churned within me while I tried to experientially comprehend my "space" in the "situation" at hand. I partly recognized it in my body, but it all hovered just beyond articulation. This part of town is a little boring, to be honest, but also relatively clean. This is maybe why it's boring and, maybe, why it matters. Someone cares for all this dull space amid the countless, monotonous, urban towers, likely because it is their own. It felt rougher before.

At the start of Krzysztof Kieślowski's Decalogue II (Dekalog II, 1989) a groundskeeper rakes the lawn. It seems futile, in the dull, dead, winter haze, but, then... a surreal discovery: a large, dead hare. Keeping things tidy must be difficult, with death all around, but this unfortunate beast is a paradoxical Christmas gift: it can feed a family, whether it has been lost over a balcony or fallen from Heaven. Being a good man, the groundskeeper knocks on every door, seeking the owner. Having been tutored by him, I wish I could meet him now, and thank him for his care.

What I mean is that I'd had an experience of a sort with him and about two dozen others in this very neighborhood. I'd inhabited it in the multisensory, sympathetic sort of way the cinema can work.[6] I'd spent years moving around that terrain in my body, exploring all its connections with my own world, to the point where it started to feel seamless.[7]

Of course, I knew these encounters were not "real life", but how much did that matter? Long ago, I'd embraced the idea that cinema traffics in deeply meaningful bodily experiences (as opposed to cold, intellectual "signs"), so I knew the dance was real. But how was it so?

[4] Ibidem, p. 159.

[5] Ibidem.

[6] I largely subscribe to an embodied simulation account of the cinema (with a heavy inflection of phenomenology). For examples, see: J.G. Kickasola, "The Senses Know: Wong Kar-Wai's Quotidian, Evanescent, and Ineffable Aesthetic", [in:] The Wiley Companion to the Films of Wong Kar-Wai, ed. M. Nochimson, London 2016, and J.G. Kickasola, "Leading with the Ear: Upstream Color and the Cinema of Res- piration", "Film Quarterly" 2013, no. 4 (66), pp. 60-74. The co-operative work between neuroscientist Vittorio Gallese and film scholar Michel Guerra has played a strong role in confirming my hunches and articulating the whole business much more coherently: Lo Schermo Empatico: Cinema e Neuroscienze, Milano 2015. [7] J.G. Kickasola, The Films of Krzysztof Kieślowski: The Liminal Image, New York 2004. 
Giuliana Bruno coined the phrase "Atlas of Emotion" for the intersection of moving images and mobile spectators. In this instance, I had brought the Atlas to the set.[8] My body was near my target destination, but how would the experiential and geographical maps align when I laid them atop each other?

To borrow terms from Bachelard, Kieślowski's Decalogue films resound with the "sonority of being".[9] I had always thought this to be true, but, on this journey, I would come to feel the ring of it all through me as my inner maps and motor programs would thrill to spaces that exceeded all I thought I knew of them. Kieślowski had placed it all in me, like a seed waiting to burst into a new stage of reality.

Empty streets and walks. People must be at work. I wandered down a long thoroughfare. Some cars passed, their hermetically-sealed inhabitants glancing curiously out at me. They didn't slow down.

I scanned for stacked crosses. Kevin Lynch calls this "legibility" in buildings, where architecture becomes a kind of marker, or a key to an environmental puzzle.[10] Those imposing, cross-shaped balconies, I now realized, were more foundational to that world than I'd first thought, but there were no crosses to be seen. I felt strangely agitated.

And then I stumbled on an orphaned space, it seemed. Dwarfed by the surrounding steel, glass, and advertising, the lonely little place toughed it out.

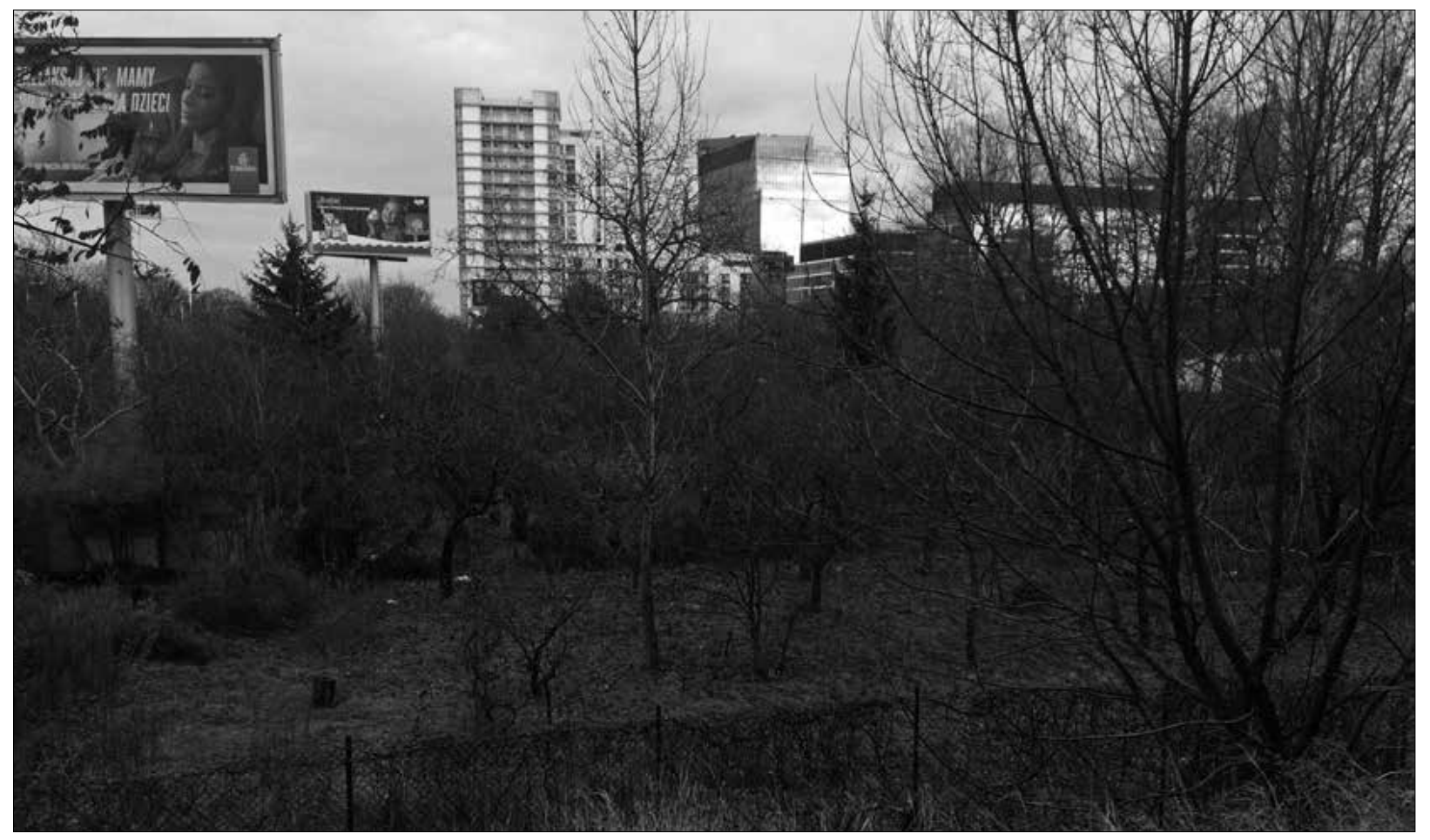

[8] G. Bruno, Atlas of Emotion: Journeys in Art, Architecture, and Film, op. cit., pp. 2-4.

[9] G. Bachelard, The Poetics of Space, Boston 1964, p. Xv.

\section{Scrabbling for Eden}




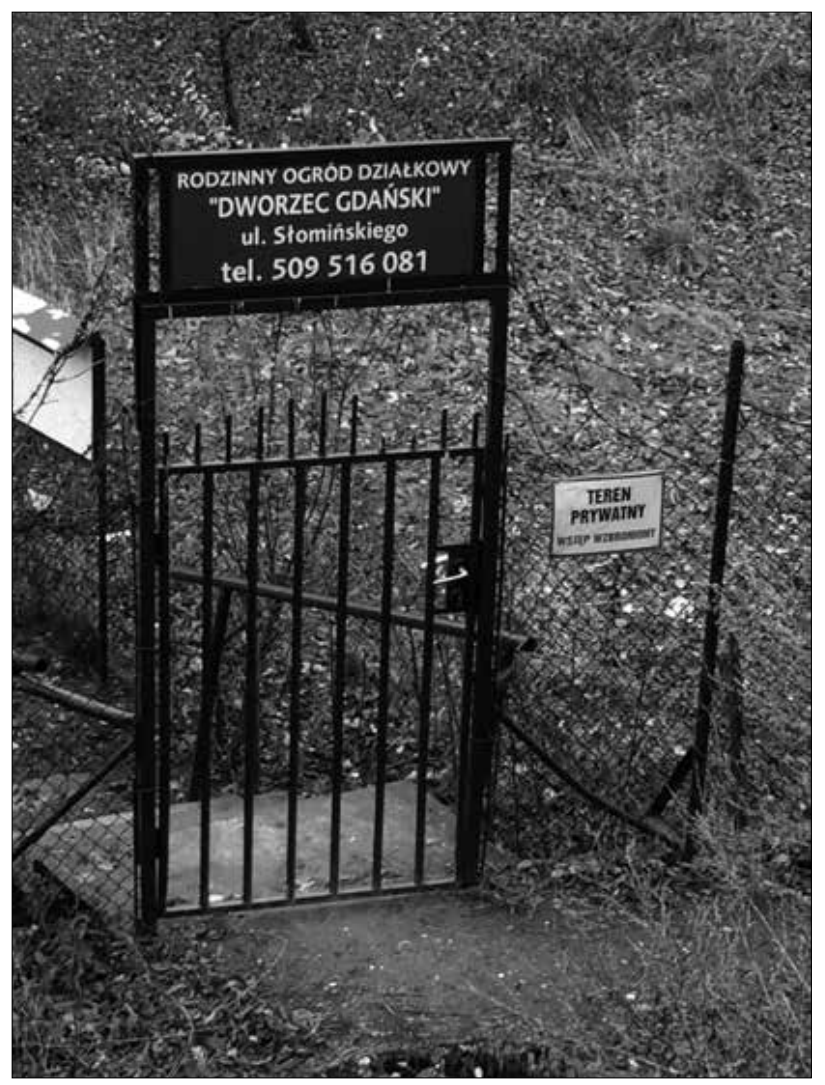

A closer inspection showed it had not been forgotten at all. It was merely November. All was retreating for the winter, but here, in an eternal negotiation with nature, cultivation fought the good fight. Here lay a bit of earth, lovingly shaped by human hands. Here stood purposeful landscape, in the human way that we seek friendship with our environment rather than conquer it. It seemed vaguely familiar to me, like an echoing sound I could not quite identify.

Rodzinny Ogród Działkowy. A "family plot garden" is something of a distinctive feature of Poland, I'm told. The working class, in particular, finds a lot of meaning in the cultivation of these places, and, as I understand it, they often pass plots down to their children, from generation to generation. One cannot live there, but it is a hiding place for hope.

The trees had mostly lost their leaves, but even now they held a promise of spring. Growing things matter. Kieślowski and his characters knew this.

The Decalogue series begins in this same, early winter, with a man wearily tending a small fire by a partially frozen lake. Snow and ice cover everything... but not sufficiently.

He looks directly at us, and says nothing. A tear escapes.

In Decalogue II the jaded Doctor finds it easier to care for his plants than his patients. Dorota, in a fit of simmering despair, cooly dismembers hers, leaf by leaf. She violently twists the stem, and Kieślowski keeps filming, ennobling this mortally wounded thing by his silent, patient witness.
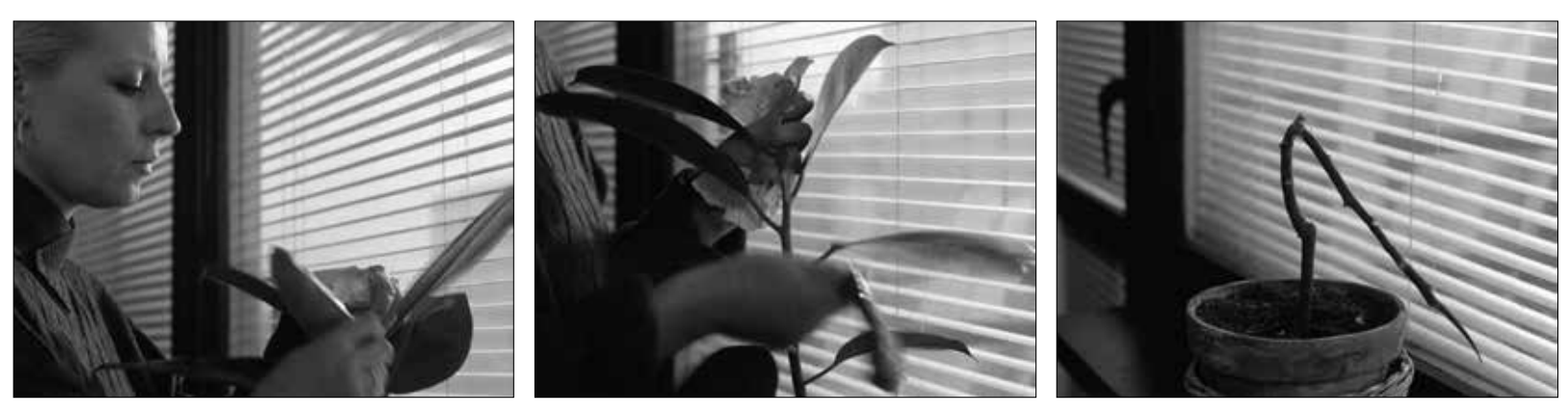

I remember first seeing that mangled plant, glacially straining upward, and the wonder of it: a strange experience of empathy for a crumpled bit of vegetation. Growing things matter, because living things matter. 
Dying things also matter.

I recalled in a new way that Decalogue moves us from winter to spring. Despite all the guilt and genocidal horror that haunts her, even Decalogue VIII's philosopher, Zofia, manages to delight in the newly green grass and freshly cut flowers. I wish, deeply, it were springtime, but I'm grateful for the season I have.

Suddenly, tucked away behind some other structures and off the main road, they emerged.

III. Sighting

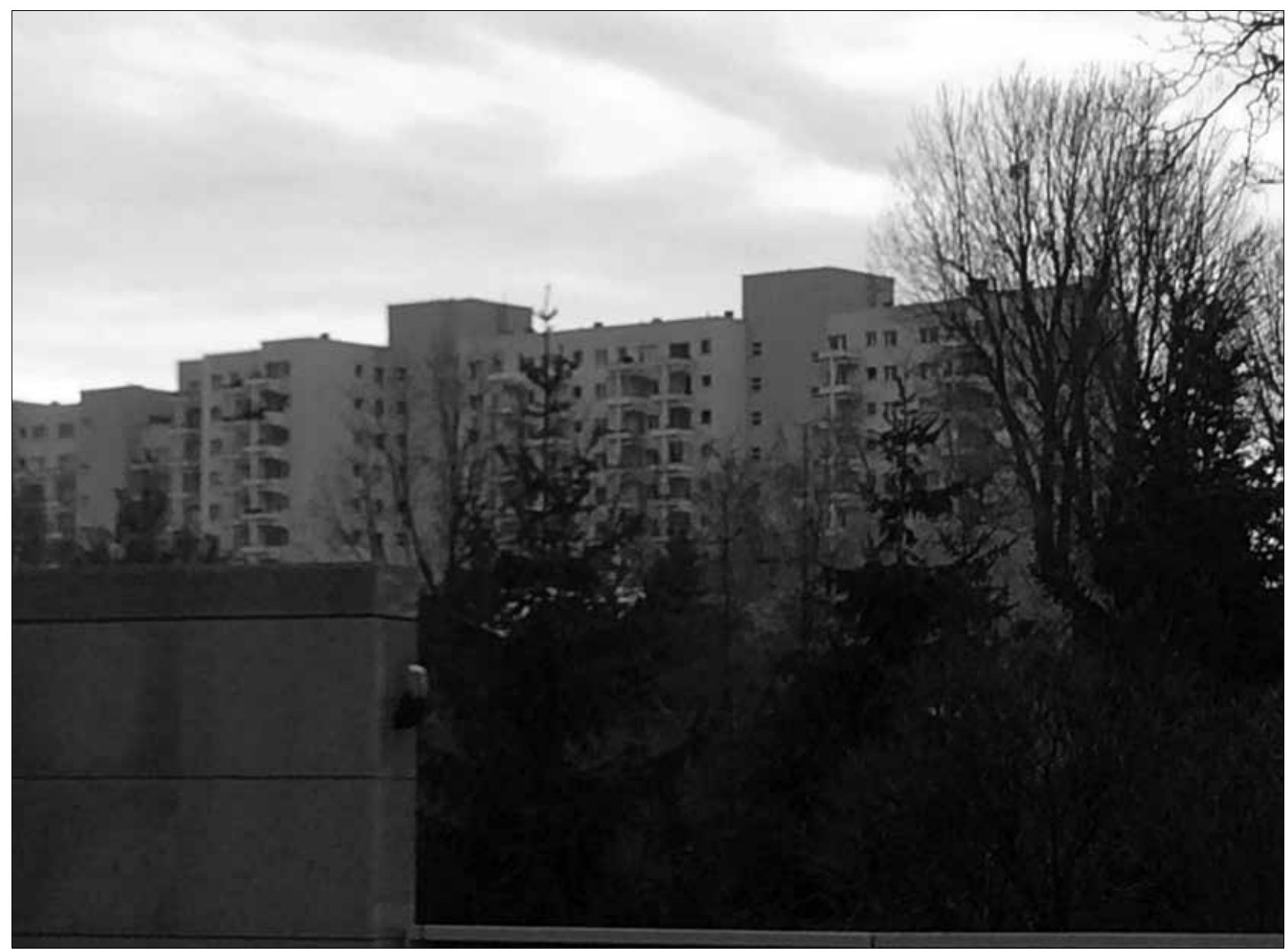

I live in New York City, so I'm familiar with the "ah" moment; the brief flash of delight when one recognizes a screen location in what we still stubbornly call "real life". It's satisfying: a slight re-alignment of one's experience of the universe. But, most often, it's also a bit of a deflation, where the ideal space-image of the cinema ends up looking and feeling remarkably small, ordinary.

Not that we mind so much. It's a wondrous kind of disappointment. Sometimes, as with studio tours and such, the experience is reduced so much that you cannot believe you were fooled into thinking the place on the screen was a "real" place, that those windows in that brownstone building lead to... nothing really. There's a kind of curious magic about all of it, but, in the end, that's what it is. Magic. Hocus-pocus. 
Eventually those little marvels domesticate themselves and become a movie of your own experience; an old script running in your head, delightful to recall, but not a full-blooded arrest of the senses like that first encounter.

And this is why I was wholly unprepared for my thunderous reaction to this ordinary apartment complex with the cross-shaped balconies. Here, in this Soviet-style complex just off Inflancka Street, within all this cold indifferent concrete, something in me surged.

\section{Breaking Barriers}

The ironies started to compound themselves. I knew, for instance, that Kieślowski chose that apartment complex precisely because it was the best among the worst of 198 os Warsaw.[11] Rather than inspiration, he wanted a routine, soul-less place, evoking the dreary, concrete-bound, Soviet-prescribed existence the Poles muddled through in that time. Unmistakably bland and endlessly replicating, its most defining feature - those stacked crosses - appeared more like prison bars than anything else to its inhabitants. By Kieślowski’s design, we desperately search for humanity in those walls, just as his characters struggle to maintain it in each other.
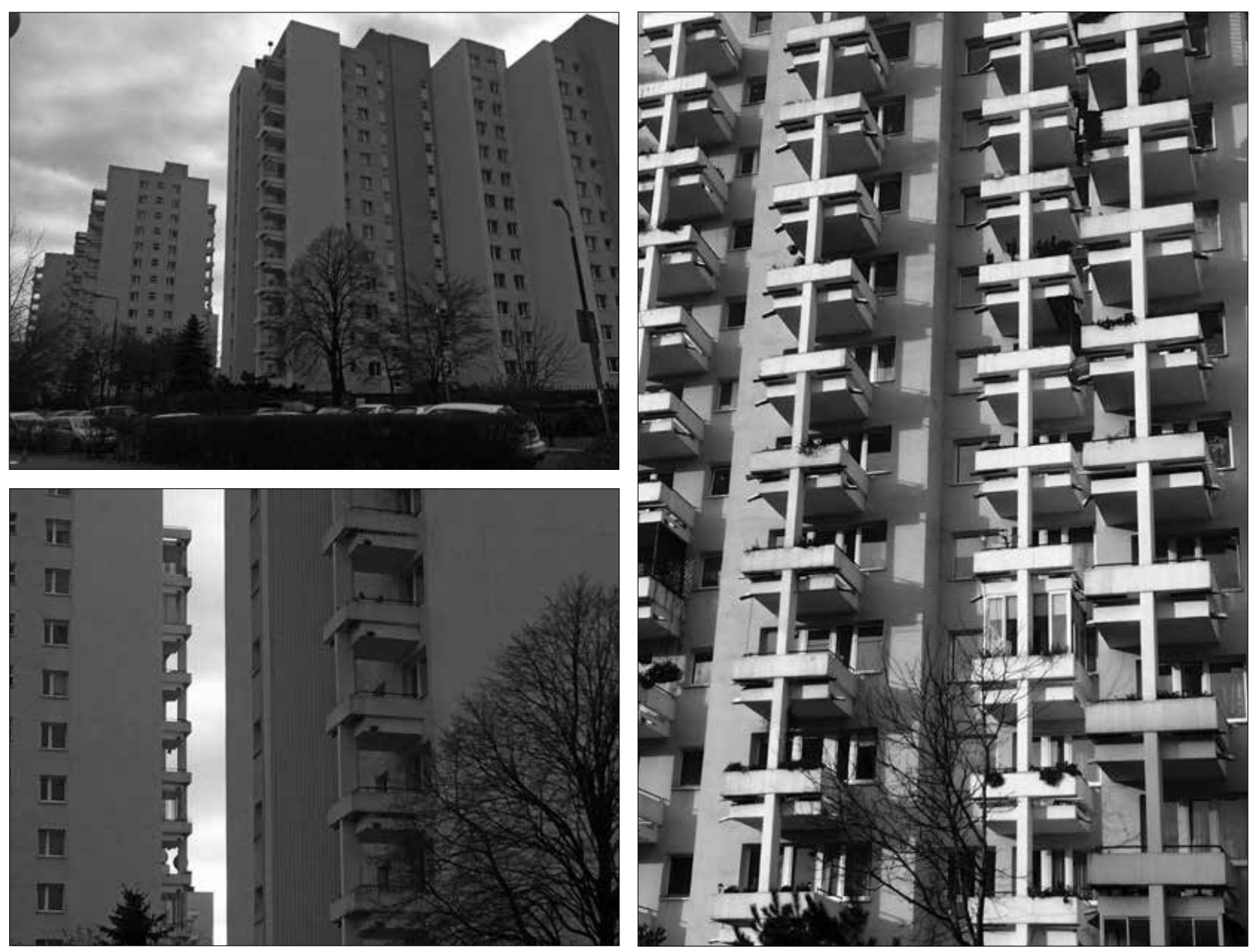

[11] "It's the most beautiful housing estate in Warsaw, which is why I chose it. It looks pretty awful, so you

can imagine what the others are like" (Kieślowski on Kieślowski, ed. D. Stok, London 1993, p. 146). 
In the films, there is no fence. One has the impression people would like to leave but simply can't muster the energy for an escape. But times have changed. Now they've put fences in, employed a security guard, and try to keep people like me out.

The bored guard reminded me of the inattentive sentry who skateboards instead of watching the monitors in Decalogue III. I thought about just asking him for a favor, to admit to my purposes and hope for understanding. Maybe he'd have pity on the presumptuous American before him who thought he knew something of this place. But then I paused, uncertain.

Most of the Decalogue residents were reluctant neighbors. They politely knew each other, but largely sheltered in place. They shared awkward, quiet moments in hallways and elevators. Sometimes they used those same lifts defensively, like the panicked mother who flies upward to escape the desperate father in Decalogue I. He frantically chases her via the stairs, wild with the need for any scrap of information on his missing son. Everyone is screaming in that scene, for no apparent reason other than a personal need for it. I can still hear those screams when I think of that scene.

The meeting of humans is so very messy and complicated, and one can never be too careful. Having a place means privacy, and security, and locks mean regulation. Just ask the brothers in Decalogue $X$, who were so very afraid and spent a small fortune on security measures. On the other hand, in a genius theme that bookends the series, Pawel and his father, in Decalogue I rig up a complicated, Rube Goldberg-like machine that would control the lock on their front door, presumably to open it for visitors. They delight in it all, seeing the wonder of technology to make things possible. But they are tragically mistaken.

Indeed, throughout Decalogue, most of the characters miscalculate their levels of control over the universe. In Decalogue VIII, that painting on the philosopher's wall just won't stay straight.

I made a spontaneous decision. A man and a woman were coming through the gate, and the guard was distracted. I walked straight in.

I meant no harm, of course, but I still felt a little ashamed.

But I felt more called than ashamed.

I didn't think a film location could thrill me anymore. What I thought I loved about the Decalogue was not the structures, but the people eking out a life in them. I knew the friends to whom Kieślowski had introduced me couldn't really live here, and there were no people around. Yet, I still felt a curious surge of excitement. I laughed at myself.

It was just so much bigger than I thought it would be; a largely rectangular arrangement of buildings with a sprawling, multi-purpose courtyard, landscaped with trees, play areas, benches, tables. Did I feel safe, as in a castle, or imprisoned, given the cruciform balconies standing like sentries all around? I could not decide. 

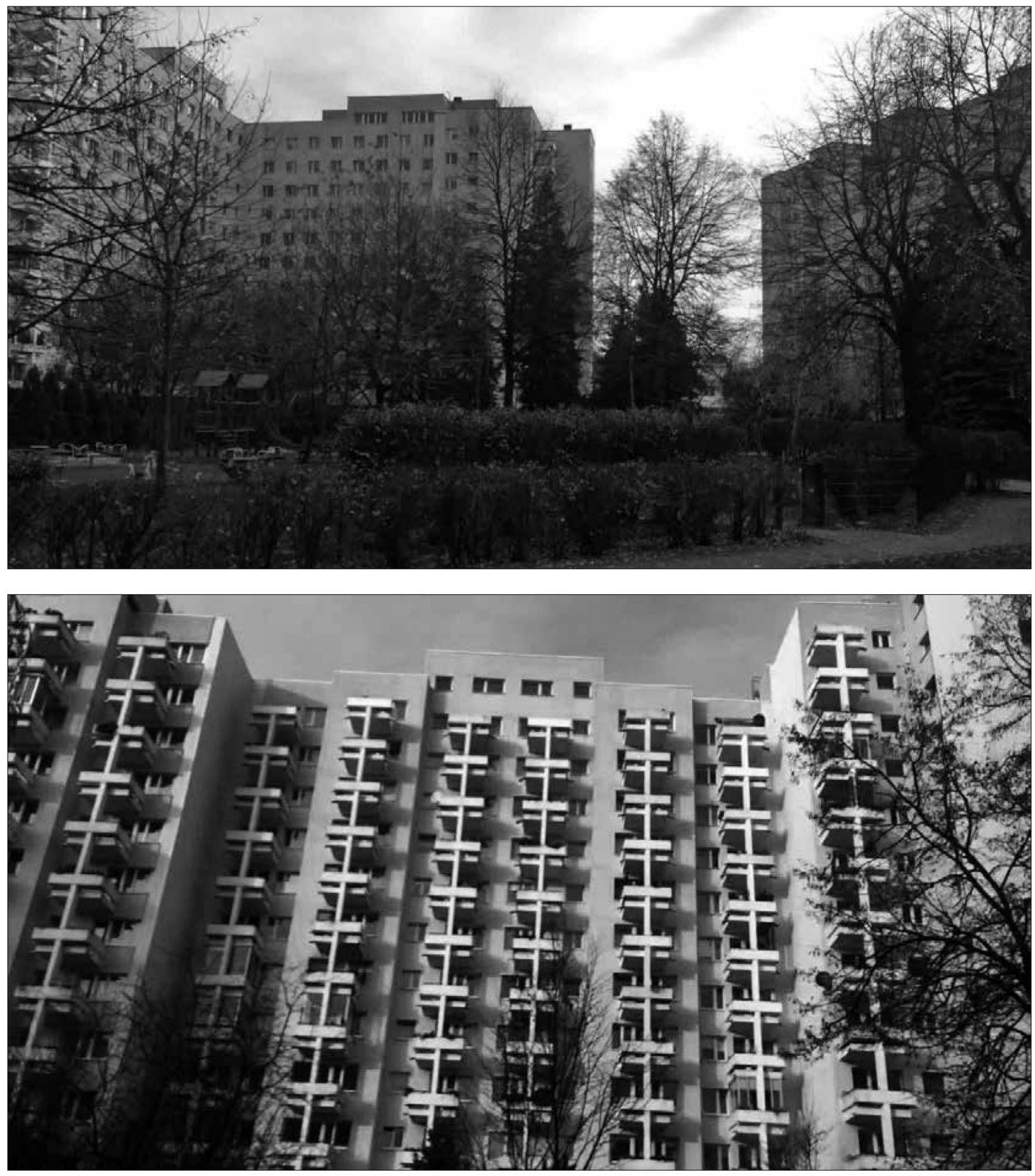

Kieślowski clearly scaled this place down; an interesting choice that points to his humanist impulses. Even so, some of his cinematographers (particularly Sławomir Idziak) grasped the visual possibilities here. And though the television format denied them the widescreen, they magnified the complex through reflections, like the extended shot of the glass door, near the beginning of Decalogue $V$. As a result, it feels less monumental, and more like a mystery unfolding: Buildings within buildings, worlds within worlds, thousands of stories tunneled throughout. 


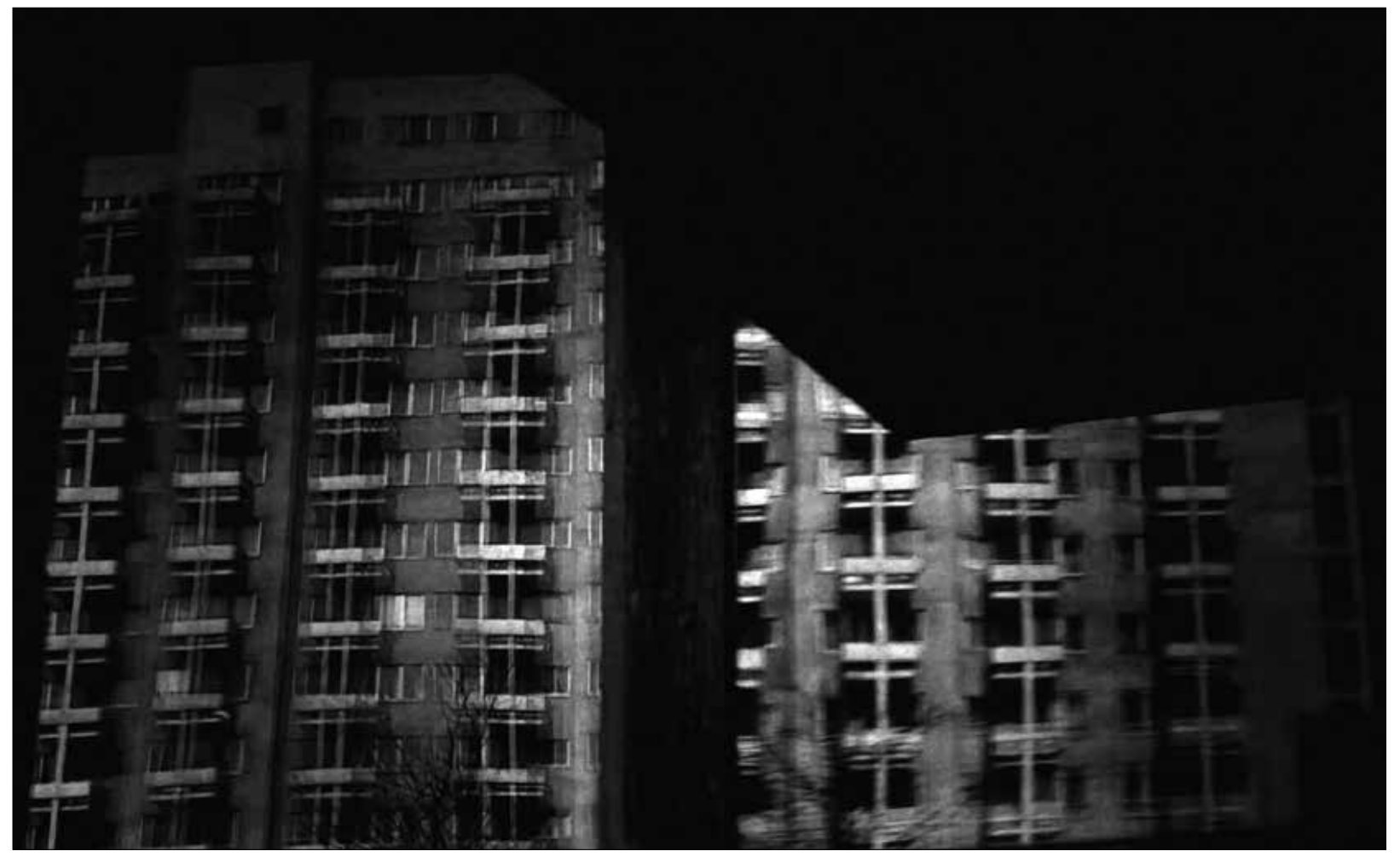

That is, until the notorious Waldemar swings open the door and disrupts everything.

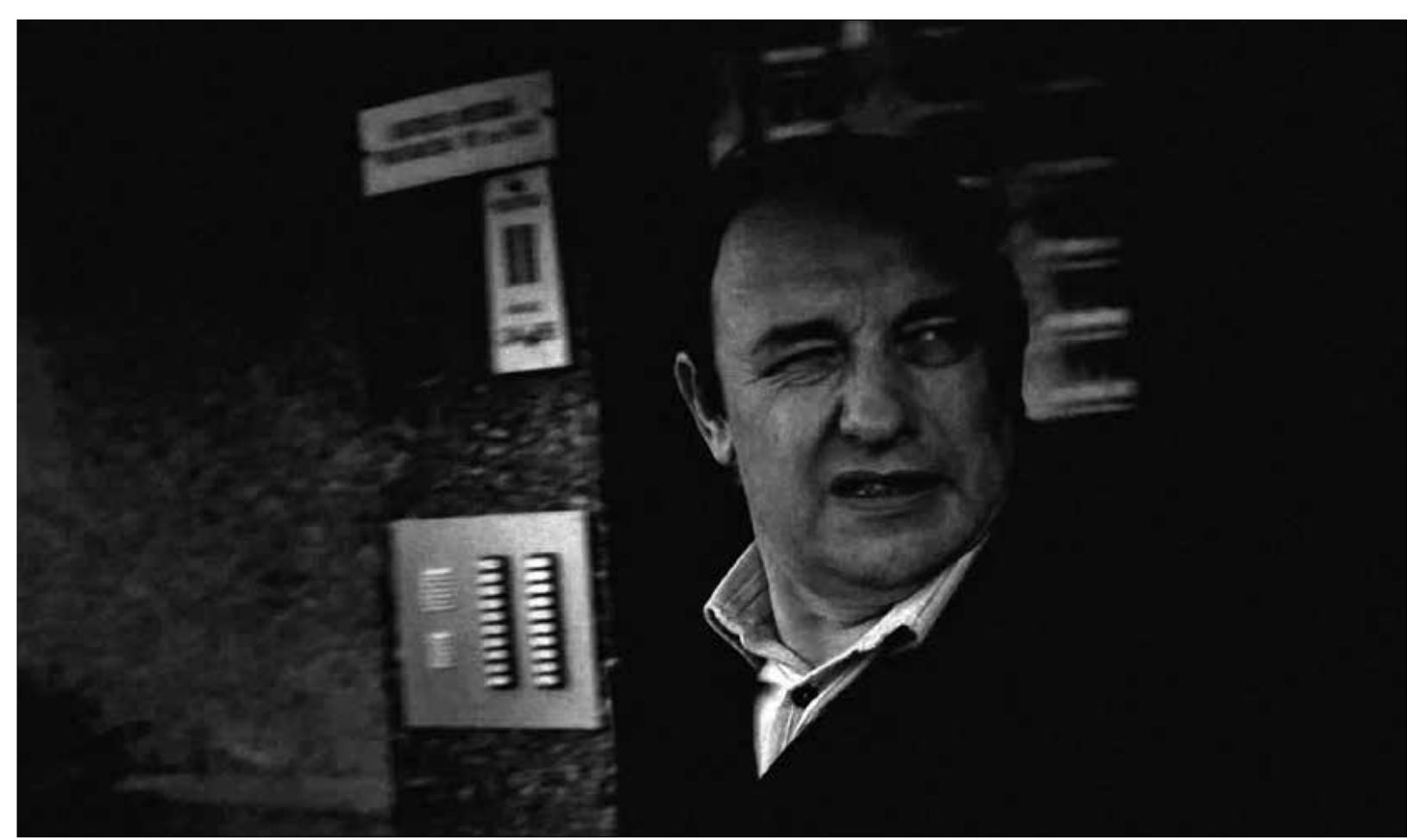

Perhaps I was not prepared to stand beneath these massive urban towers. I was dwarfed, exposed. Hitchcock was intrigued by the 
idea of neighbors seeing each other in Rear Window (1954), and that film is directly referenced more than once in Decalogue VI. An apartment complex can be a theater of humanity, with a hundred screens to choose from.

But this felt more like Bentham's panopticon, which Foucault famously analyzed.[12] Given Kieślowski’s meditations on surveillance (from the infamous cameras of Station [Dworzec, 1980] to the eavesdropping Judge in Three Colors: Red [Trois Couleurs: Rouge, 1994]), this seemed appropriate. I was fairly certain the security guard had figured me out by now. I must be on view, somewhere. How many of these apartment dwellers are gazing down at the stranger wandering the grounds, to no apparent purpose?

And then my thoughts settled enough to discover I dwelled in a sonic vacuum of sorts. So quiet. Amid all the other metaphors (castle, prison), it suddenly felt like a cloister, incredibly private and intimate, except for the thousand window-shaped eyes peering curiously down at me, unblinking.

Kieślowski and Piesiewicz first envisioned the Decalogue series as beginning in a large soccer stadium, the camera zooming around the crowd, plucking unique faces out of the sea of humanity in order to tell their individual stories.[13] I realized, in this moment, that Kieślowski had not so much abandoned the idea but transferred it to a new location. A different stadium was here, and the crowd was all around me, anonymous. I stood in the arena.

I began to think of all that happened in this common space, beneath the silent witnesses. On this path, Tomek (Decalogue VI) resignedly walked to his beating, for spying on Magda and her lover. On the other hand, he also found delirious happiness on this spot, and spun his milk cart in dizzying spirals after securing a date with that same woman, later in the film.

In Decalogue VII children squealed with delight on a playground, and I noticed swings and a slide nearby.

Violence. Self-Loathing. Love. Elation. Innocence. All here, in this place. The stories crowded in on me and I couldn't quite take it all in.

VI. Things - Living and Dead
It's not obvious in the films, but the center of the complex holds a few large trees. I would guess they are willows, or something similar. They anchor the place, like the Trees of Eden. These sturdy living things may be the only vital witnesses left, bridging Kieślowski’s marvelous efforts on that ground and my own emotional moment there. Here one stood, still, gently swaying in the wind, confident, steady, and solemn. I stared at it for a very long time.
[12] M. Foucault, Discipline and Punish: The Birth of the Prison, New York 1975.
[13] Kieślowski on Kieślowski, op. cit. 


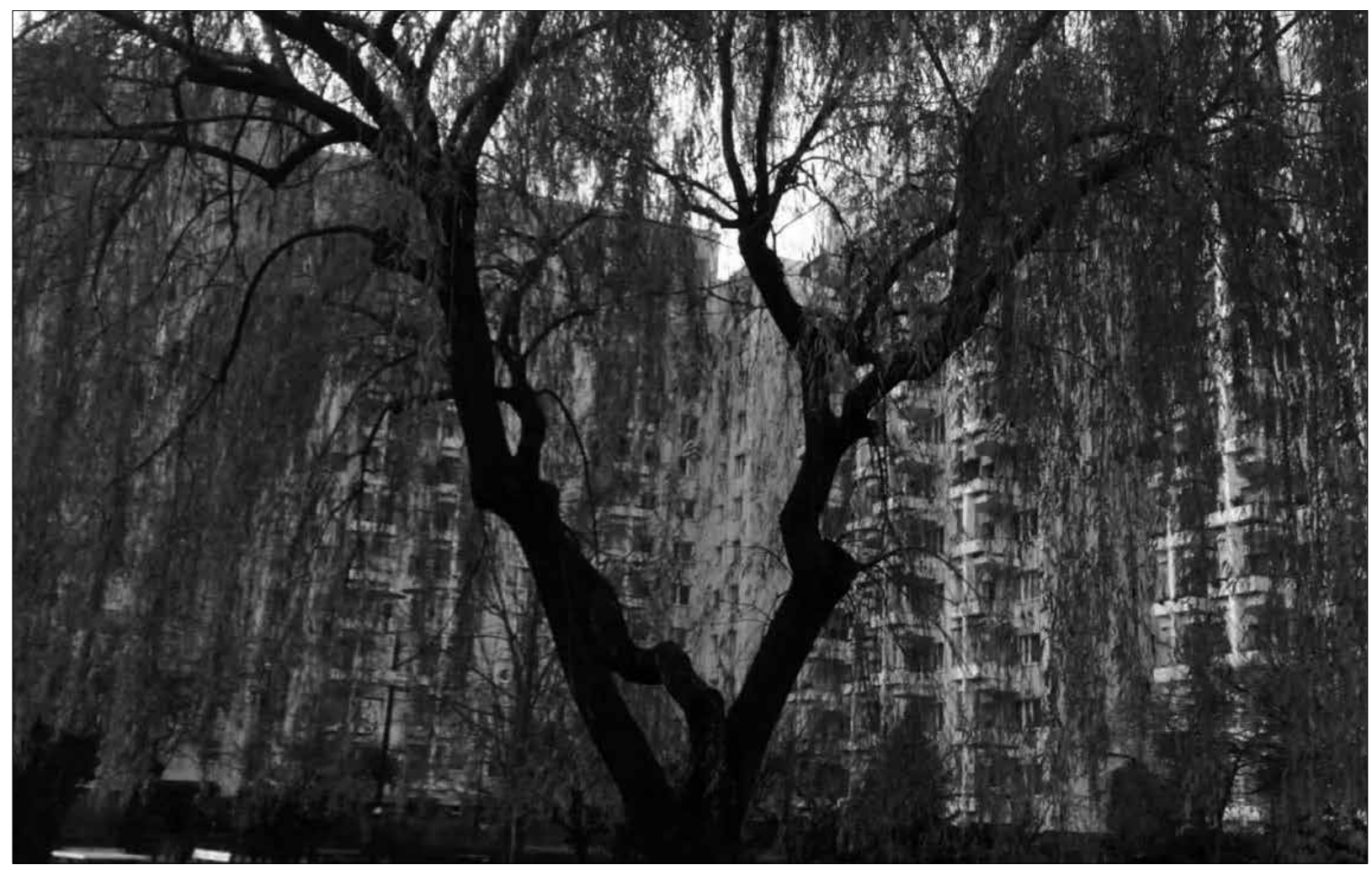

A pigeon crossed my path. I suddenly noticed them all around, and I tried to gain their attention. I succeeded and felt like a boy again.

I recalled the delightful, endlessly curious Pawel, challenging his neighbor pigeon to a staring match, in Decalogue I. Their eyes meet, and they exchange gestures. I have viewed this scene a hundred times, but this bit of mimetic communion never ceases to charm me.

I walked over to a cross shaped balcony and touched it. Of course, it was precisely what I expected it to feel like, but the point is... I felt it: a promise fulfilled. So, my body inflated to fill the shadow of the event with the real encounter. I stared up, mimicking the camera at the start of Decalogue I, and perhaps a dozen crosses towered over me. I half-understood I was waiting for the pigeons to burst across my gaze, as they do in that shot. They did not come.

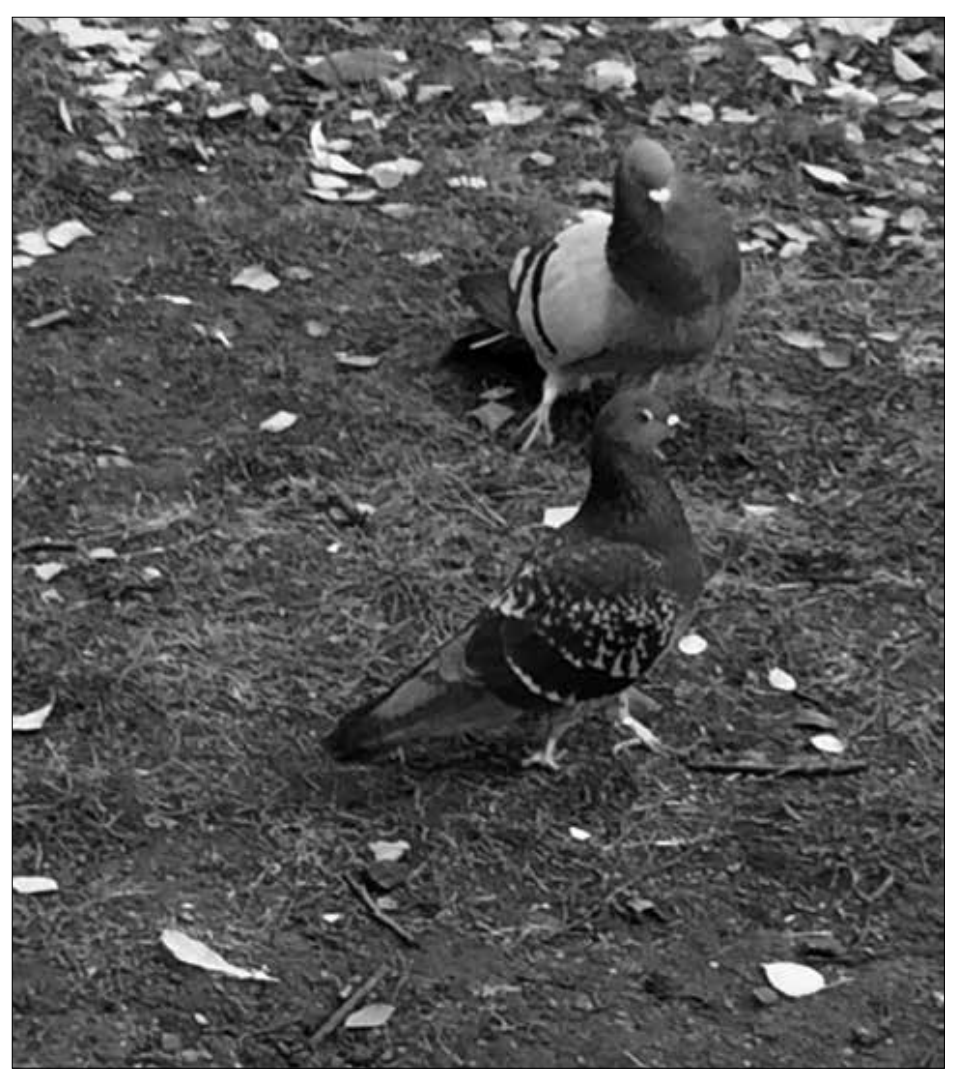




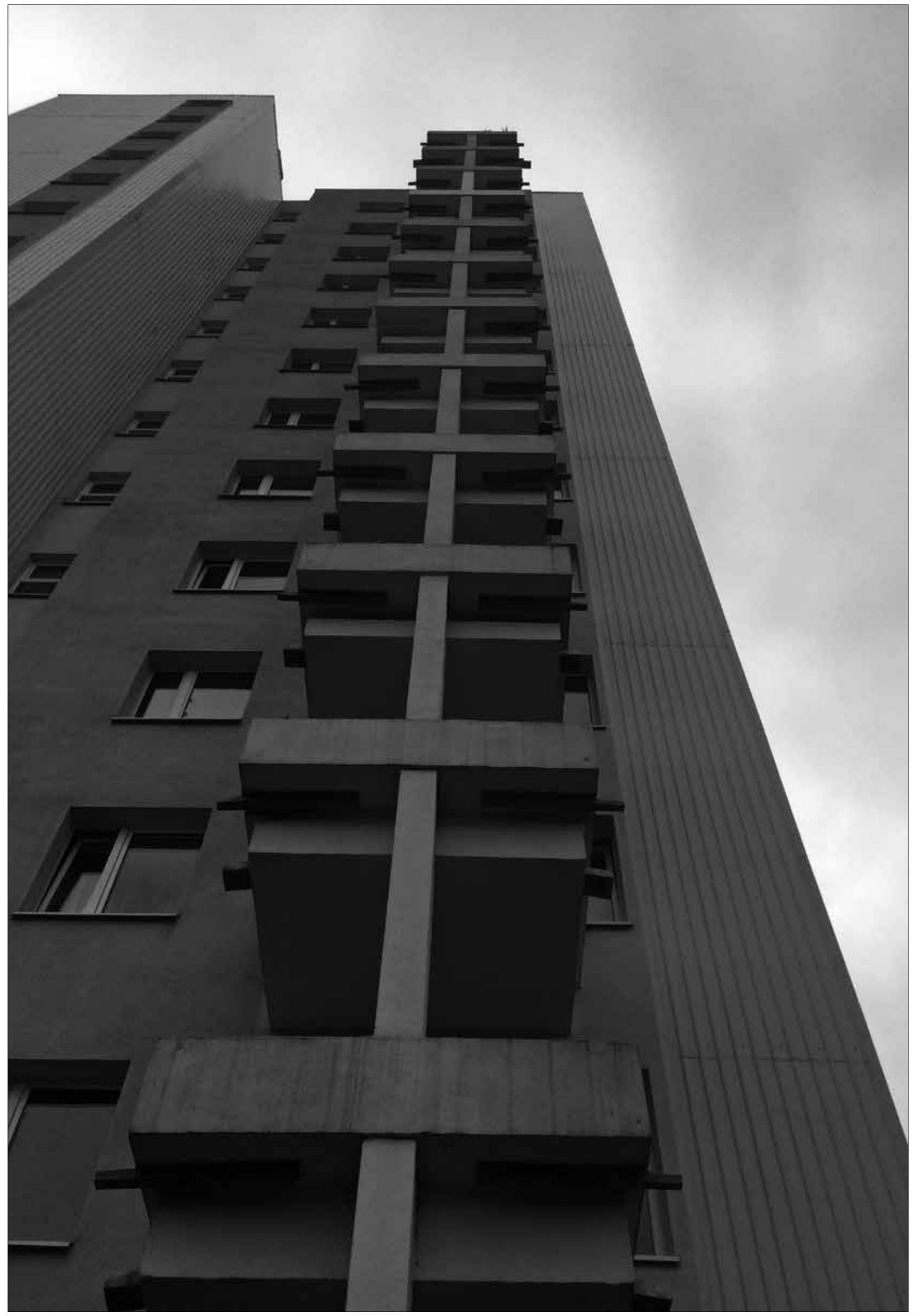


I had the strongest, most overwhelming impression that any number of the people from the Decalogue would emerge into view, at any moment. The rational part of me discounted such nonsense, of course, but my whole body groaned in anticipation of their presence. The space was inconceivable without them.

Architects write about spaces shaping people, and they do, of course. But people - even fictional people - also shape places, including those wrought in brutal concrete. Their bodies, their breath, their sound projections, their sweat, their blood: it all seeps in and does its work. To Kieślowski's credit, he had, somehow, captured the affinity between the contours of the people and the contours of the place. His films emerged where the two found their maximal fit.

I found myself looking for those faces, particularly the watchful "young man", who Kieślowski placed in nearly every episode of the series. He quietly watches me from somewhere, I thought. No one ever speaks to him, really, but I surely would have, if I could have found him.

And I realized that I simply had to do the unthinkable thing. I had to go inside.

An old woman, carrying her groceries, came up the walk, and I saw her steering toward the entrance of one of the nearby buildings. She fumbled with a key, her groceries and the heavy door. I rushed forward to help her, received a guarded smile, and I followed her in. To ease her mind, I headed past her and turned to the right, as if I knew the place.

And, in a way, I did. I saw a stairwell, which is nothing to speak of in itself, except it instantly unlocked that scene from Decalogue I, where the father, Krzysztof, grabs the rail, halts his ascent and counts to himself. He was calming himself, calling upon all his rational powers to quiet the rumbling panic in his body, because there had been an accident at

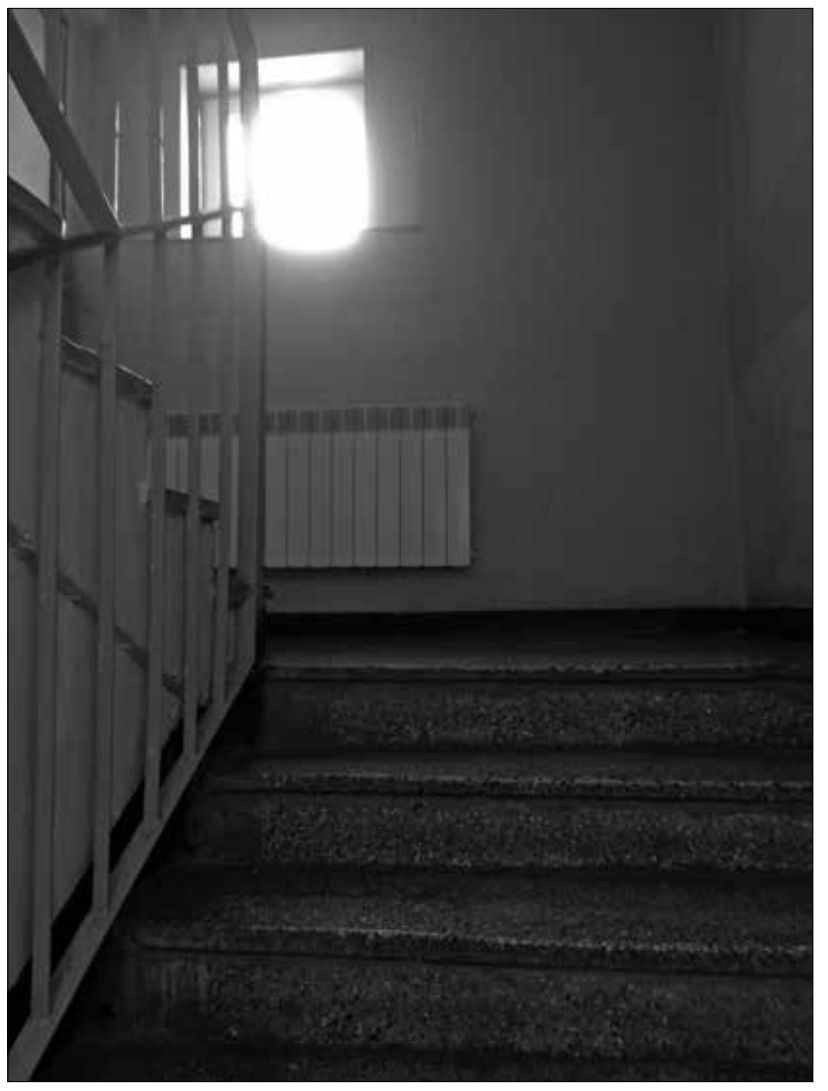
the lake and he couldn't find his son.

I grabbed the rail. And I counted. This might seem ridiculous, but it felt like a necessary ritual. Rituals hold and deliver meanings that hover beyond our words for them. As a father, I'll never forget the emotional freight of that moment in the film, where my whole being was violently quivering, about to shatter in a thousand pieces. I had been carrying that tension around for years, and I needed a proper place to release it. There, at the source, seemed fitting, accompanied by some unexpected tears. So, the emotion came home to rest. I counted on the steps, and I gripped that rail until it hurt. 


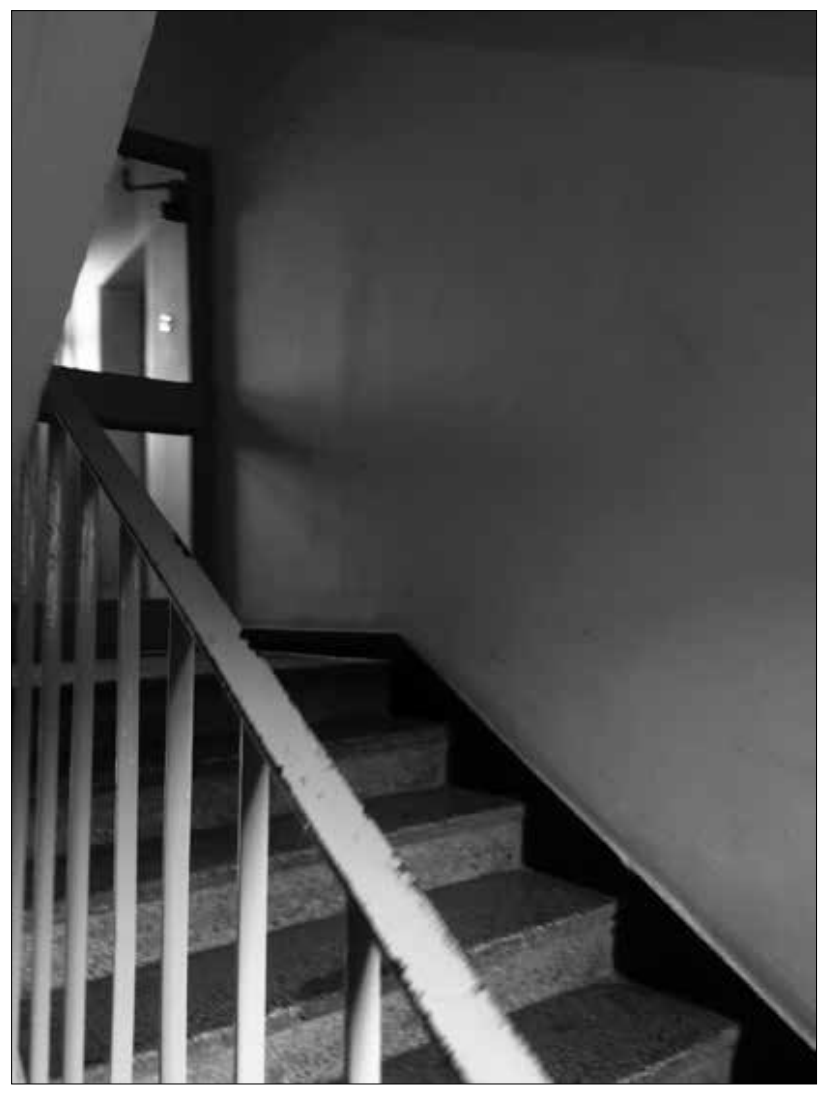

Kieślowski generated several miracles in Decalogue, and chief among them was creating a parade of ordinary people - flawed and wonderful in their own unique ways and making us feel the weight of life upon them.

I know the term "metaphysical" is unfashionable[14], but Kieślowski himself did not blush at such language. Here, it simply means above or beyond the physical; that there's much more to life and meaning than advertising, stuff we "buy in shops"[15], or "the Coca-Cola with the straw", as he once put it.[16] As Decalogue instructs us, this is also more than physics or biology or hard materialism can provide. Some of it is frightening, and some of it is beyond joyful. We operate on desire, on intuition, sensation, as they interface with rationality, judgment, principles, and traditions. We feel our way through a world of hopes and expectations, disappointments and disillusion. We love, and we lose love, and no amount of scientific description can do justice to that all of that. What's more, we worship, whether we believe or not, because we cannot not worship... something. Someone. Even if it is, tragically, our own self-interest. It's hardwired into us.[17]

It would seem that the cinema would be the materialistic medium, par excellence. Digital trickery excepted, it would seem that you only get what bounces the light rays to you.

But some artists understand how to be truly present in a place, and to properly attend to the things that reveal what is beyond them. For Decalogue, the themes, stories and characters, actors, cinematographers - countless others - stood in service to Kieślowski's uncanny understanding of human experience. Even on "the small screen" of Polish television, Kieślowski understood that whole worlds could be unlocked with one shot of a hand grasping a rail: a tactile sensation,

[14] I humbly suggest this is short-sighted. The philosopher William Desmond has done a great deal of work to rehabilitate this essential concept for modern sensibilities. See his groundbreaking Ethics and the Between, Albany, NY 2001, and more recent works. [15] Kieślowski on Kieślowski, op. cit., p. 5.

[16] "The world is not only bright lights, this hectic pace, the Coca-Cola with a straw, the new car... Another truth exists... a hereafter? Yes, surely. Good or bad, I don't know, but... something else" ([in:] A. In- sdorf, Double Lives and Second Chances: The Films of Krzysztof Kieślowski, New York 1999, p. xv [from an interview with “Télérama” 1993, September]).

[17] For additional insight, see David Foster Wallace's famous commencement address, at Kenyon College: "There is no such thing as not worshipping. Everybody worships. The only choice we get is what to worship" - D.F. Wallace, “This is Water", http:// bulletin-archive.kenyon.edu/x4280.html (accessed November 30, 2018). 
a need for steadiness, balance, a regulation of breath on the soundtrack, amid a hurricane of doubt and terror.

An ascent to the next floor and a turn reveal a hall. There's a window at the end, similar to where Dorota stood waiting in Decalogue II, hoping her dying husband's doctor would emerge. I understand why she waited. We need dull, neutral spaces to gather ourselves. Hope and despair need space to stare each other down, and the hall is a lonely DMZ between closed, locked doors. But it seems so unpromising, particularly if you so desperately need a promise. The hall is dark, so it's best to linger in the light we have and wait.
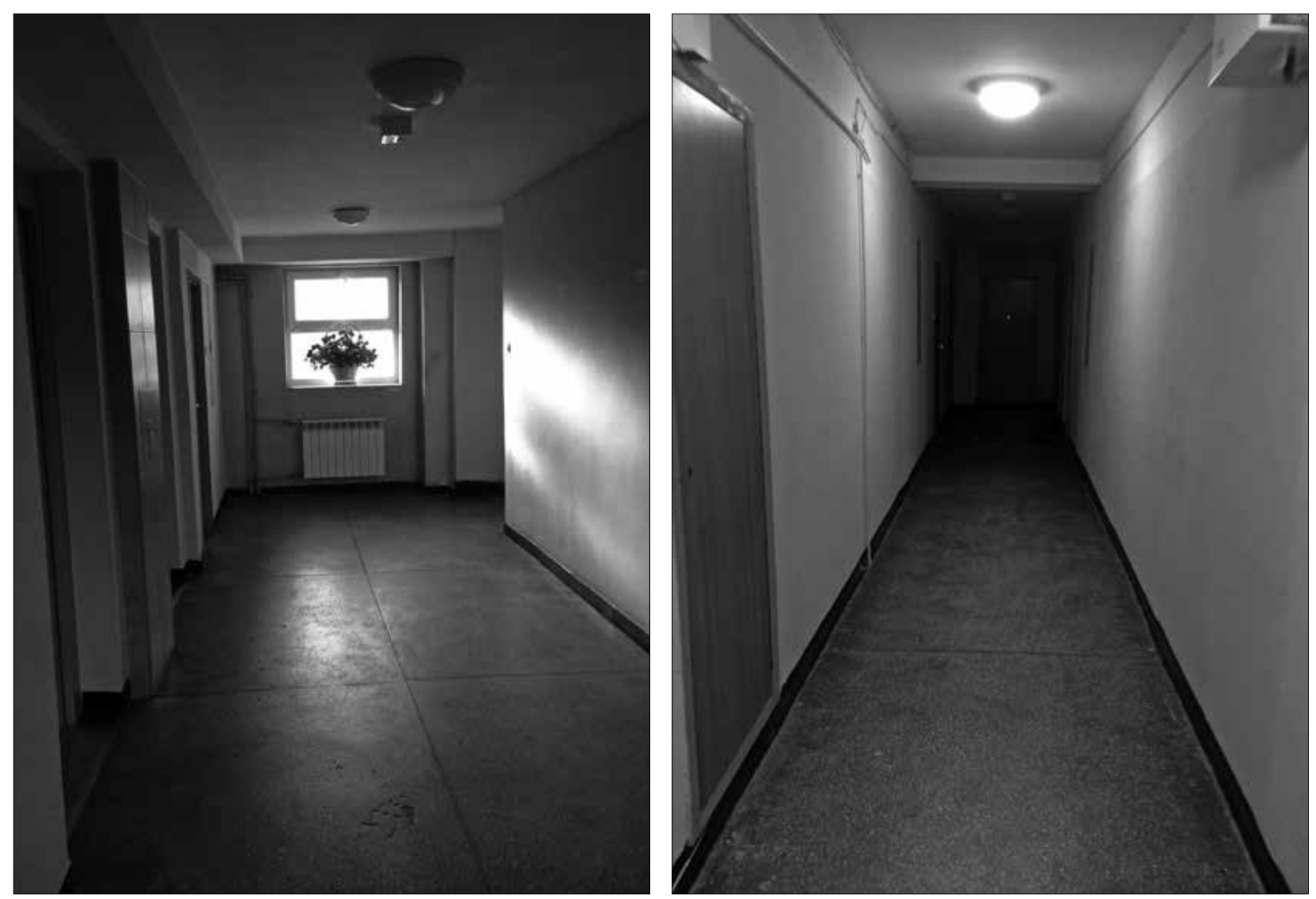

I exited the building and realized I was mimicking a tracking shot in Decalogue I, wherein Pawel exits this very building to walk to his aunt's house. I recall his lovely, anticipatory smile as the crisp winter air hits him. I remember my own boy at home, and my heart starts to ache a little.

And it was here, on this path, in Decalogue $I V$, that a father stopped in his tracks, when he heard his daughter call for him, in a miraculous, singular moment of love and clarity.

He was going to purchase milk for her, a girl who had tormented and manipulated him in numerous ways, from her own, terrible position of grief and doubt. That moment, where she yells from the window "Papa!" has always caught me as the most beautiful, moving, and miraculous bit of grace in the entire series. As a father, I was
VIII. Fathers, and All They Care for 


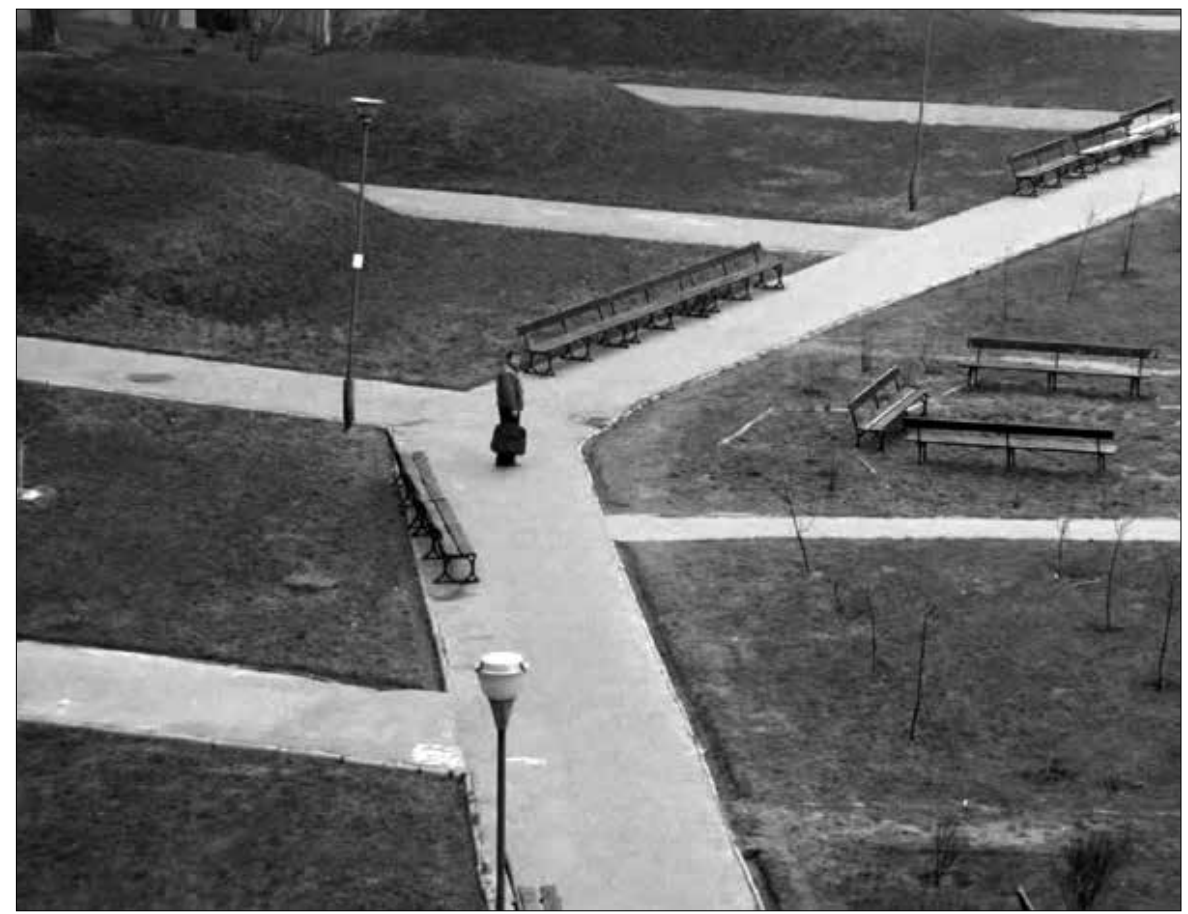

glad to stand there, where parents move in service to their families, and I longed for my loved ones to see me there, in the center of the world, calling for me by name. The place itself - one of transversal, not stasis - seemed paradoxically hallowed,

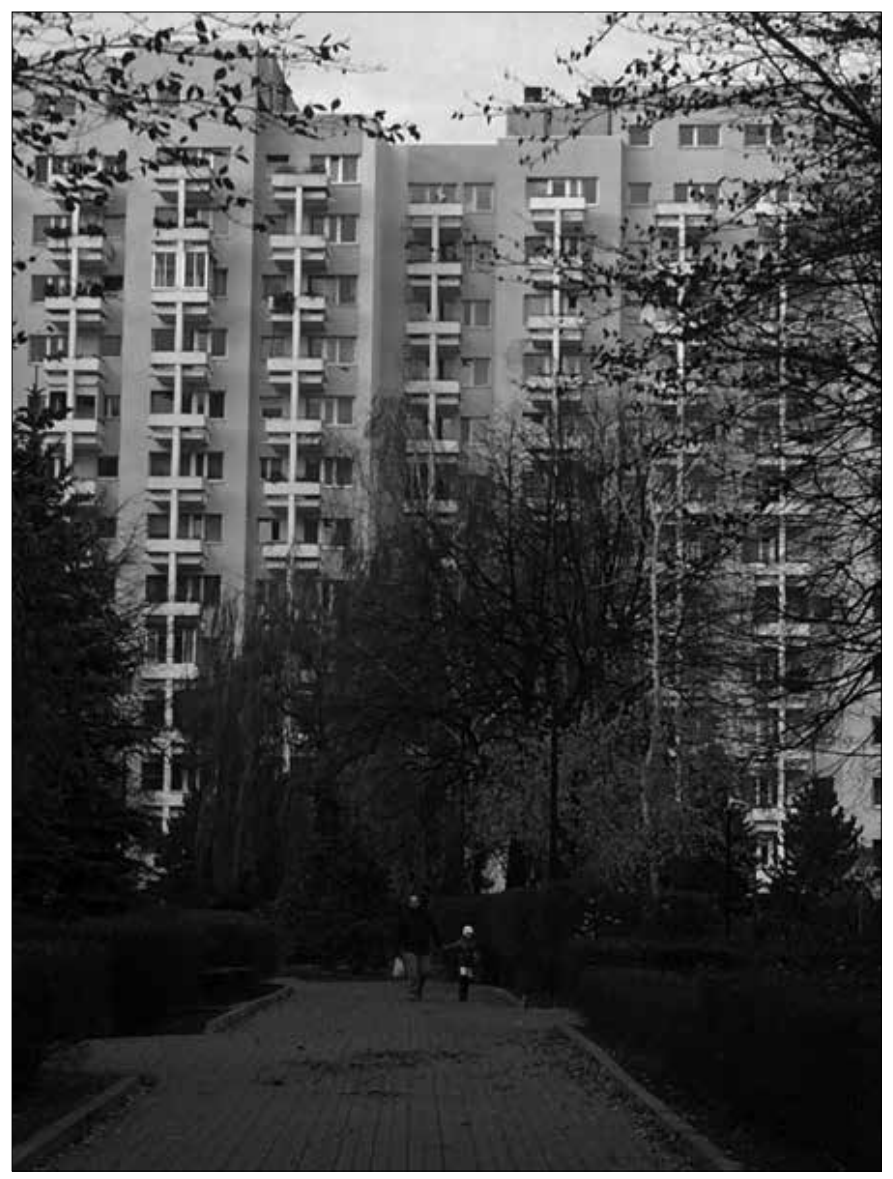
a dynamic monument to love.

And then I saw a father and his daughter hand in hand. She was much younger than the adult girl in the film. In fact, she was close to the age of Pawel's neighborhood friend, whom he happily greeted on this very path before he found the dead, frozen dog.

I was happy for them, but found myself irrationally smitten with fear. I couldn't shake the unnerving idea that the lake must be nearby. Even the most loving fathers can lose their children to its depths.

I wanted to take a closer picture, but I was ashamed. So I settled for distance, and from the hip. Kieślowski would have agreed, I imagine. He struggled to make First Love (Pierwsza miłość, 1974), and pretty much gave up documentaries shortly after that for the same reasons: intimacy is so rare, so fragile, and so precious the filmmaker really shouldn't jeopardize all that with a camera. 
But if he hadn't made First Love, or Decalogue after, I wouldn't be here witnessing this beautiful moment, this small reminder that parents love their children all over the world. I wished my daughter were here, holding my hand on the walk. We'd see this other father and daughter, and we'd talk about how parents and children, all over the world, love each other.

And I would keep my little boy away from the lake.

I had been strangely, unexpectedly, and emotionally tugged back and forth for the better part of an hour, in the surprising tide of the real world I thought I'd known cinematically. The films were not so radically different, just incomplete. It's as if the film had made the clothes, but now the real world was providing the model, filling them right up.

Effectively I'd experienced a pre-storied reality - and it mattered not at all that the stories weren't "real" in the historical sense. The imaginary feeds back into material reality and compounds it. Fictional stories and their cinematic constructions can deepen our experience, and make the world feel more lived in, more true.

The surfaces I imagined my characters touching were suddenly imminently touchable. Our shared surroundings were completely multi-dimensional, calling me to a type of communion that miraculously aligned our worlds. In all this haptic contact, nothing magical happened, but everything ordinary happened in all its fullness.

One of the great secrets of Decalogue is its multisensory appeal, how - through some bit of extraordinary genius - Kieślowski could make you feel the reality of those stories.[18] Those affections and sensations sunk deep in me and rested at the core of my nervous system. They hung around the joints and marrow, like sleeping giants, waiting for the moment that they'd be marshaled back into action. Perhaps, when I entered Inflancka, they jumped to attention because they'd come home, in a way.

My brain could not understand my emotional response to this place, but my body knew the kinship of it, and so a whole world of experience was unlocked in me, eager to be reincarnated. My whole being lurched toward the dance, and I found I knew the steps. Merleau-Ponty would smile at this, no doubt.

It is exceptionally difficult to write about intuitions, bodily responses, and the array of biophysical fluctuations we experience at any given moment. As for me, Kieślowski, and Inflancka: it was a grand surprise of the ordinary. The habitat did not deflate, as so many cinematic spaces have, but inflated and swelled to fulfill the multisensory, multidimensional promise the Decalogue had always offered. It was the full payment, following a deposit made in a different decade, a different time.

Good cinema is film well carried and lived through after.

[18] See: J.G. Kickasola, "The Synaesthetic Immediate in Kieslowski's Decalogue", [in:] Of Elephants and Toothaches: Ethics, Politics, and Religion in Krzysztof

\section{Knowing When to Leave}

Kieślowski's "Decalogue", eds. M. Parmeggiani and E. Badowska, New York 2016. 
In the life after death - and I hope for it - perhaps it will be a bit like this: a million experiential deposits, roaring back to the surface for abundant, vibrant collection.

But in this life, as well as cinema, there are limits. It occurred to me that one last frontier remained: to get inside someone's apartment. I rationalized that this was natural: I'm not a voyeur, but a voyageur, eager to know all I can about the lovely places and people I encounter; to make friends, to know the ground they walk on, the earth they cultivate, and to render praise and honor for all their love and struggle. I hope I watch cinema out of love, for all the world has given me.

But that is an awfully idealistic view of myself, and I simply can't go in someone's apartment. I shouldn't. There are limits, and they protect me as well as everyone else. Best to sit with the joy I have, and carry it all with me to the next adventure. And so, with those mercifully restraining thoughts, I rested on a bench in the courtyard.

I kept thinking that if I hung around more experiences would emerge. But one has to know when to leave a charged moment, to stop living it and start reflecting. So, I walked out through the gate, holding a sturdier, more hopeful world than when I came.

I didn't need to look back, so I didn't.

X. Something like an Ending

Kieślowski's grave is not too far away; a mere 20-minute walk. As I traversed the way from Inflancka to Powązki Cemetery, I knew I was living, in those liminal minutes, far more than the average $1 / 3$ of an hour holds. The stories kept churning in my head, animated by the encounter I'd had, and I kept laughing at myself: because I couldn't keep the tears from coming, as the truths - the cascading human truths of love, life, striving, desperation, death, and hope for something more beyond it all - kept washing over me. Then, before I knew it, the ordered, concrete land of the living slipped into the scattered, labyrinthine, stone-marked land of the dead.
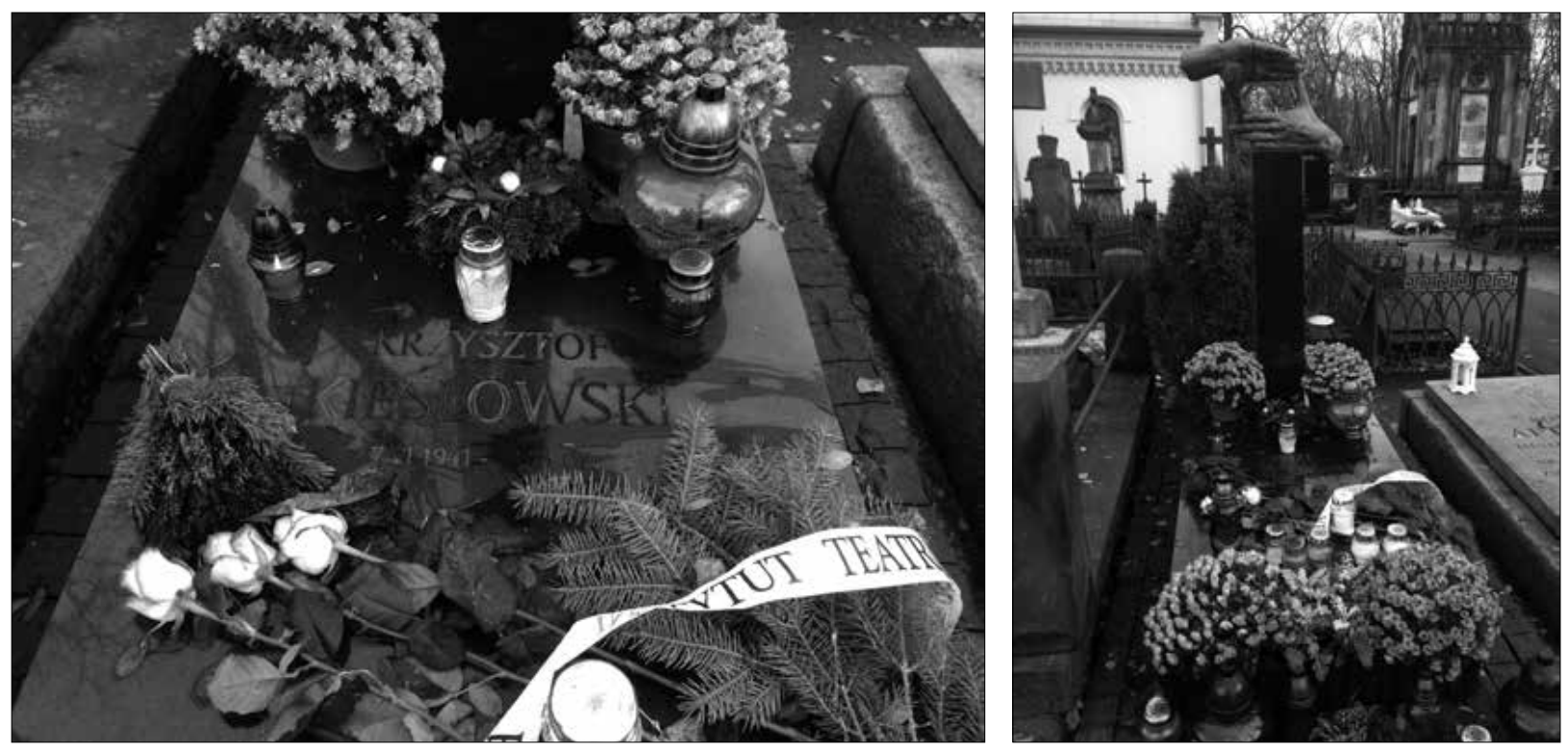
When I reached his grave, I was struck with how unadorned it is, but many loving people had filled it up with color.

Of course, the famous hands, fashioned after his own, held their iconic frame.

And I was sad. The tragedy of it hit me again; the compassionate genius, and all the stories we lost when we lost him.

The hands atop that grave create a hole. A void. A nothing.

But then I shifted my eyes and started to see the world again, through them.

Thank God I still can.

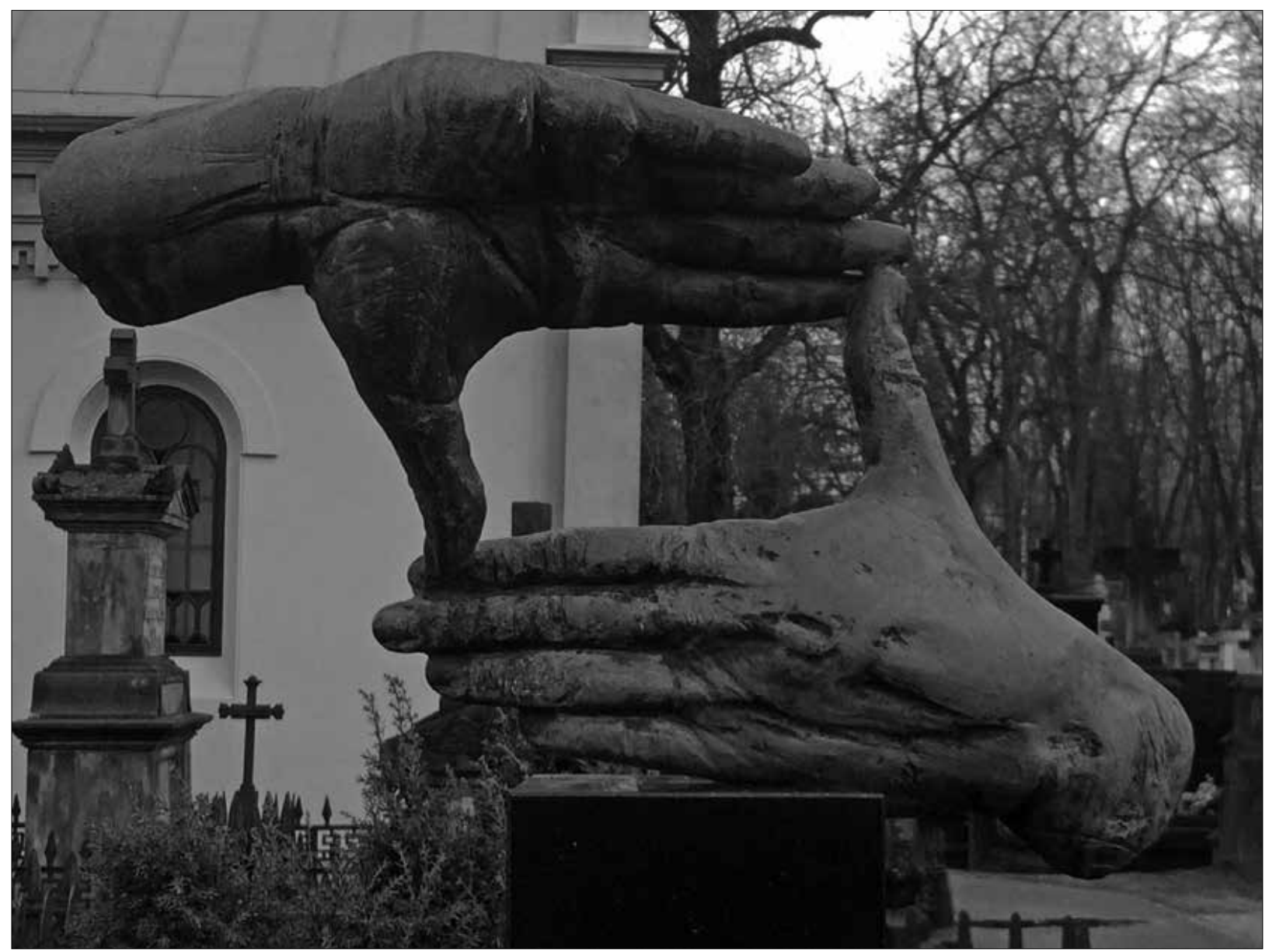

Bachelard G., The Poetics of Space, Boston 1964

Bruno G., Atlas of Emotion: Journeys in Art, Architecture, and Film, Cambridge, MA 2002

Desmond W., Ethics and the Between, Albany 2001

Foucault M., Discipline and Punish: The Birth of the Prison, New York 1975

Gallese V. and Guerra M., Lo Schermo Empatico: Cinema e Neuroscienze, Milano 2015

Insdorf A., Double Lives and Second Chances: The Films of Krzysztof Kieślowski, New York 1999

Kickasola J., The Films of Krzysztof Kieślowski: The Liminal Image, New York 2004 
Kickasola J.G., "Leading with the Ear: Upstream Color and the Cinema of Respiration", "Film Quarterly" 2013, no. 4 (66), pp. 60-74

Kickasola J.G., "The Senses Know: Wong Kar-Wai's Quotidian, Evanescent, and Ineffable Aesthetic", [in:] The Wiley Companion to the Films of Wong Kar-Wai, ed. M. Nochimson, London 2016

Kickasola J.G., "The Synaesthetic Immediate in Kieslowski's Decalogue", [in:] Of Elephants and Toothaches: Ethics, Politics, and Religion in Krzysztof Kieślowskis "Decalogue", eds. M. Parmeggiani and E. Badowska, New York 2016 Kieślowski on Kieślowski, ed. D. Stok, London 1993

Lynch K., The Image of the City, Cambridge, MA 1960

Merleau-Ponty M., Phenomenology of Perception, tran. C. Smith, London 2002

Wallace D.F., "This is Water", http://bulletin-archive.kenyon.edu/x4280.html (accessed November 30, 2018) 